\title{
1.2. OIL-PRICE VOLATILITY AND EXTERNAL RISK: IMPLICATIONS FOR THE MACROECONOMIES OF CENTRAL AND EASTERN EUROPE
}

\begin{abstract}
Summary
In an era of increased global risk and the possibility of international "contagion," managers worldwide must be cognizant of the role that various types of volatility might have on their countries and regions. In particular, statistical analysis can provide estimates of the macroeconomic implications of shocks to foreign asset and commodity prices. This study performs such an analysis, applying time-series econometric modelling to analysis of four Central European countries (Bulgaria, Croatia, Hungary, and Poland), as well as Russia and Ukraine.

Using monthly data and applying Vector Autoregressive (VAR) time-series methods, this study first models oil-price volatility and real effective exchange-rate volatility. We then study the effects of these volatility terms and of changes in U.S. stock prices on credit growth, output growth, and the currency markets of our set of European countries. Overall, Granger Causality tests and Impulse Response Functions show that risk does have a strong impact on the region's economies, but that the effects differ from country to country. For example, U.S. stock-price declines uniformly put pressure on the region's currencies. At the national level, oil-price volatility puts pressure on the złoty (PLN) and also contributes to Polish growth, and also hurts Russian growth. Our findings therefore offer the region's industries insights into their exposure to global risk and the global macroeconomy.
\end{abstract}

Keywords: Commodity prices, volatility, Central Europe, Eastern Europe, time series

\section{Introduction}

Following a decade of large increases and decreases on global markets, commodity prices began to drop significantly in 2014. While the resulting revenue losses can hurt emerging-market commodity exporters, oil-price declines may help lower costs and boost profits for manufacturers, particularly in Central and Eastern European (CEE) nations. At the same time, however, large swings in commodity prices create volatility that might be detrimental; increased risk hurts individual businesses and the overall macroeconomy. This paper investigates the impact of oil-price volatility on the exchange markets of six CEE nations, as well as interactions with macroeconomic variables. Using time-series methods, we find important effects that differ from country to country.

This study focuses on a measure of Exchange-Market Pressure (EMP), which captures exchange-rate depreciations as well as central-bank measures to combat these depreciations. This monthly measure is then modelled as a function of U.S. stock prices and key macroeconomic variables. These include domestic credit growth, the growth rate of government borrowing, GDP growth, and inflation. Previous research, by Phylaktis and Ravazzolo (2005), Van Poeck et al. (2006), Stavárek (2011), Koseoglu and Cevik (2013) and others shows these variables to be significant determinates of EMP and currency crises in the CEE region. And while Hegerty (2012, 
2014a, 2014b) examines the link between commodity price changes and EMP in Latin America, Russia, and the Baltics, he does not include price variability in any specification. This study, therefore provides a key addition to this important branch of the literature, providing business leaders with increased ability to understand and mitigate this risk.

\section{Methodology}

In this study, monthly data for all variables are taken from the International Financial Statistics of the International Monetary Fund. The timespan differs from country to country, but generally begins in the mid-1990s and ends in late 2014. First, we calculate EMP as a function of exchange-rate depreciations (an increase in the number of units per U.S. dollar), reserve losses (as a percentage of the lagged monetary base), and the change in the interest-rate differential (money-market rate) vis-à-vis the United States:

$$
E M P_{t}=\frac{1}{\sigma_{\Delta e}}\left(\ln E_{t}-\ln E_{t-1}\right)-\frac{1}{\sigma_{\Delta R E S}} \frac{\Delta R E S_{t}}{M B_{t-1}}+\frac{1}{\sigma_{\Delta r}} \Delta\left(r_{t}-r_{t}^{U S}\right)
$$

Each component is deflated by its own standard deviation. Oil-price volatility is next calculated as the standard error of a rolling AR(1) regression (of the price on its lagged value), with 12-month windows. A similar calculation is carried out with the real effective exchange rate (REER), which represents a country's competitiveness versus a broad range of trade partners. This volatility, therefore, represents another type of external risk.

After plotting these time series, we then conduct Vector Autoregressive (VAR) analysis to test for spillovers among variables. These allow for any variable in the specification to have an impact on any other; for example, EMP and growth might have effects on each other. We first perform a bivariate Granger Causality test between oil-price and REER volatility to see whether the addition of one variable to a regression of the other on its own lagged values increases the regression's explanatory power; if so, it has a significant impact. Our main test, however, is this test's multivariate version, applied to the following vector:

\section{$[$ EMP,CRG, GOVGGROWTH,INF, d $\ln U S P S$, POIL VO]}

The lag length of each VAR is chosen by minimizing the Schwarz goodness-of-fitcriterion. In addition, we make sure that each variable in our analysis is stationary by performing a set of Phillips-Perron (1988) stationary tests, and taking first differences of any variable for which we are unable to reject the null hypothesis of nonstationarity. We therefore proceed with VARs that contain different mixes of differenced and level variables, all of which are stationary. Once proper VARs are estimated, significant Granger Causalty/Block exogeneity statistics suggest that one variable has an effect on the variable of interest.

We also generate a number of Impulse-Response Functions (IRFs) following the Generalized VAR methodology of Pesaran and Shin (1998). These functions plot the time path of one variable after a shock to another, as well as significance bands to 
show whether these responses differ from zero. While the "orthogonal" VAR approach of Sims (1980) depends on the proper ordering of variables in the system, the "generalized" approach does not. In an additional analysis, we re-estimate Equation (2) with volatility of the REER in place of oil-price volatility, for a total of 12 separate estimations.

Our Granger Causality results and Impulse Response Functions are shown below. Overall, we find that not only does each of the six countries in our analysis behave differently from one another for almost every variable, but that REER volatility and oil-price variability also generate surprisingly different results.

\section{Results}

Figure 1 shows the calculated time series of in the price of U.K. Brent and its volatility from 1990 to 2014. We see increases in volatility throughout the sample period, but the largest "spike" occurs immediately before and during the 2008 Global Financial Crisis. At the same time, EMP increased during this period, as did real exchange-rate volatility for these CEE countries. Our goal is to test empirically the causes and interlinkages of these movements.

Figure 1: Oil Prices (U. Brent) and their volatility

POILB (log changes in U.K. Brent price) VOLPOILB (volatility in oil price)

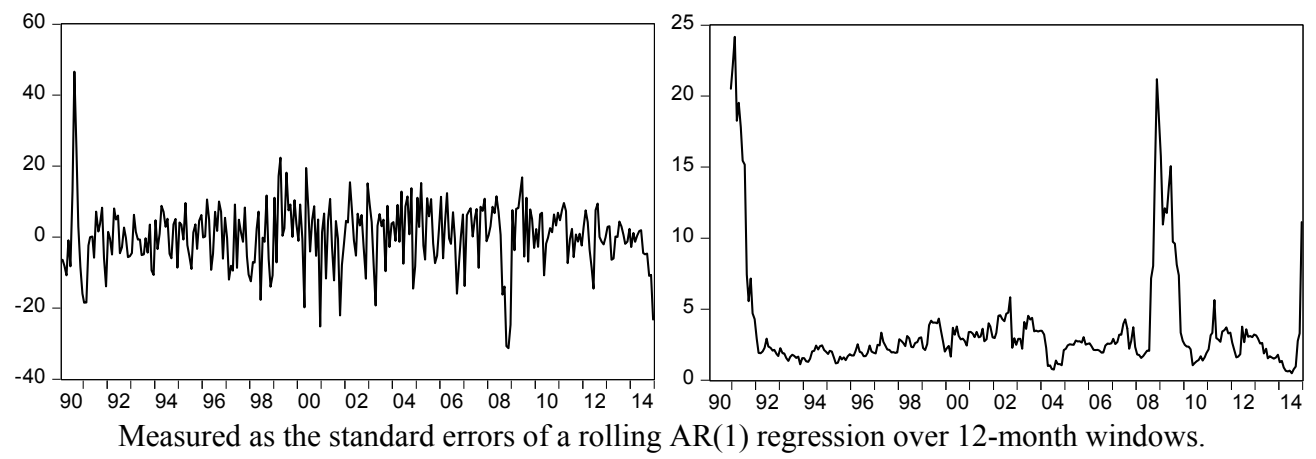

The left side of Figure 2 shows our generated EMP series. Market pressure increased during the 2008 crisis - note the behaviour of the złoty, for example - but this pattern is similar across countries. Each country has its own "idiosyncratic" behaviour as well, which represents it unique internal conditions (Bulgaria, for example, behaves differently from the others). On the right side is REER volatility. Again, there are "common" events, such as the 2008 crisis, as well as individual movements (Hungary's stands out during 2012). 
Figure 2: Exchange market pressure indices (left side) and REER volatility (right side)

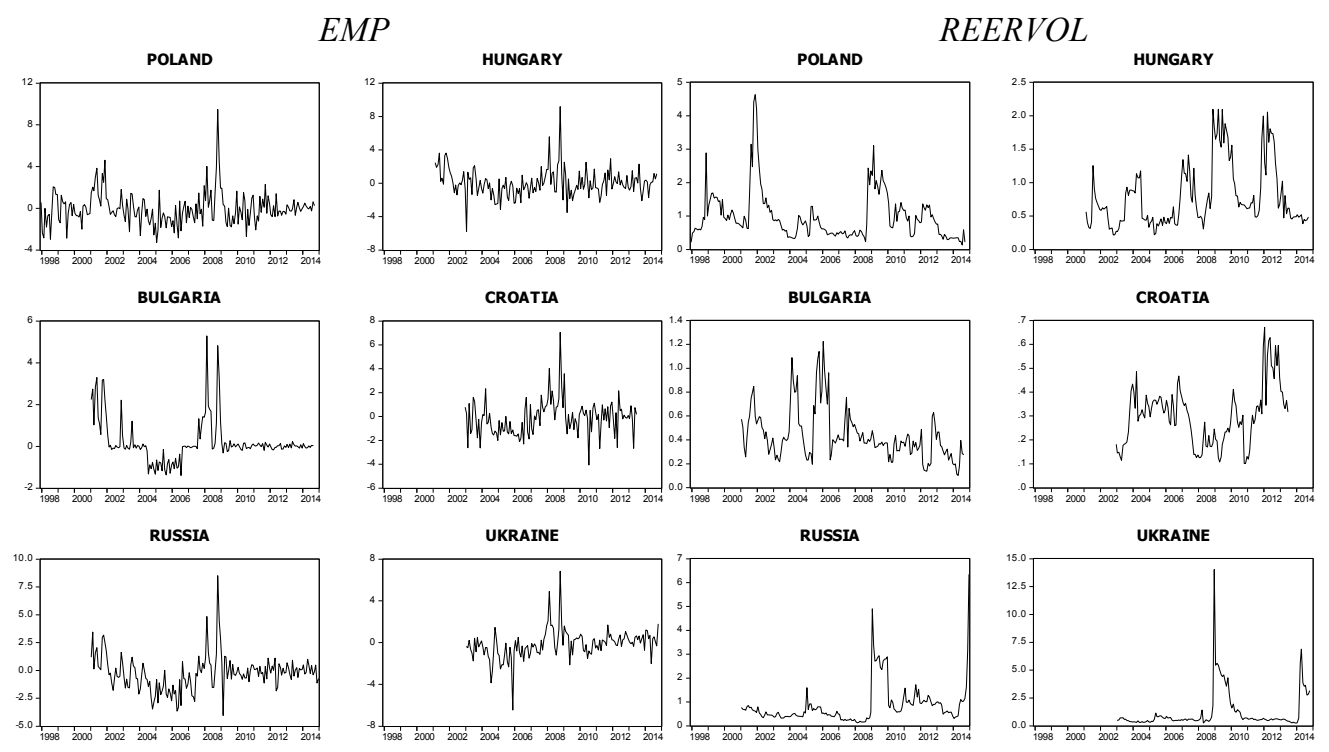

Before proceeding with our econometric analysis, we first conduct the Phillips-Perron (1988) stationarity test.

Table 1: Phillips-Perron stationary test results

\begin{tabular}{lllllll} 
Variable & Bulgaria & Poland & Hungary & Croatia & Russia & Ukraine \\
\hline EMP & -5.126 & -9.143 & -9.805 & -8.726 & -6.771 & -7.123 \\
& $(0.000)$ & $(0.000)$ & $(0.000)$ & $(0.000)$ & $(0.000)$ & $(0.000)$ \\
CRG & -2.063 & -2.453 & -2.066 & -2.277 & -2.730 & -1.490 \\
& $(0.260)$ & $(0.127)$ & $(0.258)$ & $(0.180)$ & $(0.069)$ & $(0.538)$ \\
GOVG & -14.089 & -3.474 & -2.475 & -2.948 & -12.456 & -8.598 \\
& $(0.000)$ & $(0.009)$ & $(0.122)$ & $(0.040)$ & $(0.000)$ & $(0.000)$ \\
GROWTH & -3.167 & -6.038 & -4.011 & -5.087 & -3.168 & -2.063 \\
& $(0.022)$ & $(0.000)$ & $(0.001)$ & $(0.000)$ & $(0.022)$ & $(0.260)$ \\
INF & -2.102 & -2.513 & -2.022 & -2.437 & -2.263 & -1.735 \\
& $(0.244)$ & $(0.112)$ & $(0.277)$ & $(0.132)$ & $(0.184)$ & $(0.413)$ \\
DLNUSPS & -10.406 & & -10.423 & -8.674 & -10.671 & -9.310 \\
& $(0.000)$ & & $(0.000)$ & $(0.000)$ & $(0.000)$ & $(0.000)$ \\
VOLPOILB & -2.909 & -3.297 & -2.913 & -2.634 & -2.904 & -2.734 \\
\multirow{2}{*}{ REERVOL } & $(0.044)$ & $(0.015)$ & $(0.044)$ & $(0.086)$ & $(0.045)$ & $(0.068)$ \\
& -4.460 & -4.034 & -4.034 & -3.157 & -1.473 & -4.968 \\
& $(0.000)$ & $(0.001)$ & $(0.001)$ & $(0.023)$ & $(0.547)$ & $(0.000)$ \\
\hline
\end{tabular}

$\mathrm{P}$-values in parentheses. $\mathrm{H}_{\mathrm{o}}=$ the variable is nonstationary.

Macroeconomic variables are often "nonstationary," rising or falling over time. This makes traditional statistical inference difficult, so one solution is to difference the variables when necessary and to include only changes over time in our analysis. The 
results of our test, which tell us which variables need to be differenced and which do not, are presented in Table 1.

EMP, for example, is always stationary without differencing, while credit growth must be differenced for all six countries (and would be labelled "DCRG" to reflect this adjustment). GDP growth must be differenced for Ukraine, but not Poland, for example.

We next test for direct spillovers between volatility measures using a bivariate Granger-causality test. The results are provided in Table 2.

Table 2: Bilateral Granger causality test results (p-values in parentheses)

\begin{tabular}{lllllll} 
& Poland & Hungary & Bulgaria & Croatia & Russia & Ukraine \\
\hline \multirow{2}{*}{ REER $\rightarrow$ POILB } & 0.288 & 3.774 & 0.360 & 2.502 & 0.457 & $\mathbf{3 . 9 8 9}$ \\
& $(0.599)$ & $(0.054)$ & $(0.549)$ & $(0.116)$ & $(0.500)$ & $\mathbf{( 0 . 0 4 8 )}$ \\
POILB $\rightarrow$ REER & $\mathbf{6 . 6 4 5}$ & $\mathbf{1 0 . 6 4 4}$ & 0.016 & 0.435 & $\mathbf{8 . 8 4 4}$ & $\mathbf{4 2 . 2 4 5}$ \\
& $\mathbf{( 0 . 0 1 1 )}$ & $\mathbf{( 0 . 0 0 1 )}$ & $(0.898)$ & $(0.511)$ & $\mathbf{( 0 . 0 0 3 )}$ & $\mathbf{( 0 . 0 0 0 )}$ \\
\hline
\end{tabular}

Bold = significant at 5 percent. $\mathrm{H}_{\mathrm{o}}=$ the left-hand variable does not Granger-cause the righthand one.

We see that in four of the six countries, increased oil-price variability spills over to the real effective exchange rate. In other words, oil price risk leads to risk in the "terms of trade," or the competitiveness of the CEE region. Only in Ukraine is the other direction of causation significant at 5 percent. Perhaps world markets are sensitive to events in this relatively small, but highly influential country.

Table 3 shows the main Granger causality/Block exogeneity test results. Variables are differenced based on stationarity tests results that are available upon request.

Table 3: Bilateral Granger causality test results (p-values in parentheses)

\begin{tabular}{|c|c|c|c|c|}
\hline Poland & EMP & DCRG & GROWTH & DINF \\
\hline EMP & & $0.578(0.447)$ & $14.785(0.000)$ & $0.604(0.437)$ \\
\hline DCRG & $0.116(0.733)$ & & $7.790(0.005)$ & $7.696(0.006)$ \\
\hline GROWTH & $0.572(0.449)$ & $1.349(0.245)$ & & $6.097(0.014)$ \\
\hline DINF & $0.063(0.802)$ & $14.217(0.000)$ & $9.793(0.002)$ & \\
\hline DGOVG & $1.182(0.277)$ & $0.156(0.693)$ & $2.077(0.150)$ & $1.227(0.268)$ \\
\hline DLNUSPS & $2.526(0.112)$ & $0.666(0.414)$ & $0.316(0.574)$ & $0.070(0.791)$ \\
\hline DVOLPOILB & $0.777(0.378)$ & $6.892(0.009)$ & $0.241(0.624)$ & $0.212(0.645)$ \\
\hline All & $5.138(0.526)$ & $25.643(0.000)$ & $28.004(0.000)$ & $18.152(0.006)$ \\
\hline Hungary & EMP & DCRG & DGROWTH & DINF \\
\hline EMP & & $1.901(0.168)$ & $0.307(0.579)$ & $0.136(0.712)$ \\
\hline DCRG & $1.934(0.164)$ & & $0.145(0.703)$ & $0.000(0.993)$ \\
\hline DGROWTH & $0.143(0.705)$ & $0.058(0.810)$ & & $2.393(0.122)$ \\
\hline DINF & $0.035(0.851)$ & $3.233(0.072)$ & $0.38(0.538)$ & \\
\hline DGOVG & $2.365(0.124)$ & $2.187(0.139)$ & $3.793(0.052)$ & $0.179(0.673)$ \\
\hline DLNUSPS & $1.629(0.202)$ & $0.252(0.616)$ & $0.131(0.717)$ & $2.881(0.090)$ \\
\hline DVOLPOILB & $0.410(0.522)$ & $0.803(0.370)$ & $2.489(0.115)$ & $0.343(0.558)$ \\
\hline All & $4.928(0.553)$ & $12.316(0.055)$ & $13.958(0.030)$ & $7.815(0.252)$ \\
\hline
\end{tabular}




\begin{tabular}{|c|c|c|c|c|}
\hline Bulgaria & EMP & DCRG & DGROWTH & DINF \\
\hline EMP & & $0.557(0.456)$ & $3.634(0.057)$ & $0.336(0.562)$ \\
\hline DCRG & $0.830(0.362)$ & & $0.008(0.927)$ & $0.456(0.500)$ \\
\hline DGROWTH & $0.965(0.326)$ & $0.494(0.482)$ & & $0.357(0.550)$ \\
\hline DINF & $0.250(0.617)$ & $0.635(0.425)$ & $0.148(0.701)$ & \\
\hline GOVG & $0.000(0.993)$ & $0.136(0.712)$ & $0.315(0.575)$ & $0.063(0.802)$ \\
\hline DLNUSPS & $6.018(0.014)$ & $7.991(0.005)$ & $0.152(0.696)$ & $5.156(0.023)$ \\
\hline DVOLPOILB & $1.051(0.305)$ & $0.011(0.916)$ & $0.003(0.957)$ & $0.001(0.979)$ \\
\hline All & $9.207(0.162)$ & $9.461(0.149)$ & $4.927(0.553)$ & $6.496(0.370)$ \\
\hline Croatia & EMP & DCRG & GROWTH & DINF \\
\hline EMP & & $0.092(0.762)$ & $0.771(0.380)$ & $0.213(0.645)$ \\
\hline DCRG & $1.270(0.260)$ & & $0.001(0.974)$ & \\
\hline GROWTH & $0.449(0.503)$ & $0.003(0.957)$ & & $0.608(0.435)$ \\
\hline DINF & $0.324(0.569)$ & $1.599(0.206)$ & $0.491(0.484)$ & $0.725(0.394)$ \\
\hline DGOVG & $1.105(0.293)$ & $0.048(0.827)$ & $0.825(0.364)$ & $0.475(0.491)$ \\
\hline DLNUSPS & $1.634(0.201)$ & $0.267(0.605)$ & $0.428(0.513)$ & $0.084(0.772)$ \\
\hline DVOLPOILB & $0.558(0.455)$ & $4.633(0.031)$ & $0.159(0.690)$ & $9.475(0.002)$ \\
\hline All & $4.423(0.620)$ & $9.790(0.134)$ & $4.492(0.610)$ & $11.50(0.074)$ \\
\hline Russia & EMP & DCRG & DGROWTH & DINF \\
\hline EMP & & $1.099(0.295)$ & $4.986(0.026)$ & $0.437(0.508)$ \\
\hline DCRG & $0.007(0.933)$ & & $3.484(0.062)$ & $0.001(0.978)$ \\
\hline DGROWTH & $1.794(0.180)$ & $2.947(0.086)$ & & $2.585(0.108)$ \\
\hline DINF & $0.701(0.402)$ & $2.200(0.138)$ & $0.802(0.371)$ & \\
\hline DGOVG & $0.332(0.565)$ & $1.623(0.203)$ & $0.090(0.764)$ & $0.192(0.662)$ \\
\hline DLNUSPS & $2.832(0.092)$ & $0.503(0.478)$ & $4.546(0.033)$ & $0.026(0.871)$ \\
\hline DVOLPOILB & $0.729(0.393)$ & $0.886(0.347)$ & $4.415(0.036)$ & $0.175(0.676)$ \\
\hline All & $5.804(0.446)$ & $9.916(0.128)$ & $25.082(0.000)$ & $3.105(0.796)$ \\
\hline Ukraine & EMP & DCRG & DGROWTH & DINF \\
\hline EMP & & $1.280(0.258)$ & $2.023(0.155)$ & $0.754(0.385)$ \\
\hline DCRG & $2.172(0.141)$ & & $0.040(0.841)$ & $1.630(0.202)$ \\
\hline DGROWTH & $1.340(0.247)$ & $9.834(0.002)$ & & $6.294(0.012)$ \\
\hline DINF & $0.748(0.387)$ & $4.783(0.029)$ & $1.262(0.261)$ & \\
\hline GOVG & $0.214(0.644)$ & $2.849(0.091)$ & $2.094(0.148)$ & $0.020(0.887)$ \\
\hline DLNUSPS & $1.152(0.283)$ & $0.187(0.665)$ & $4.785(0.029)$ & $3.277(0.070)$ \\
\hline DVOLPOILB & $0.252(0.616)$ & $0.036(0.849)$ & $0.487(0.485)$ & $0.172(0.678)$ \\
\hline All & $6.789(0.341)$ & $26.01(0.000)$ & $14.872(0.021)$ & $14.232(0.027)$ \\
\hline
\end{tabular}

Our key item of interest is the effect of oil-price volatility on EMP, credit growth, GDP growth (proxied by log changes in the monthly index of industrial production), and CPI inflation. Our main finding is that CEE exchange markets are less affected by commodity-price risk than are other variables. Oil-price volatility has a significant impact on credit growth in Poland and Croatia and on GDP growth in Russia. U.S. stock-price movements significantly affect EMP growth in Poland and Croatia and industrial-production (GDP) growth in Russia. U.S. stock-price movements significantly affect EMP, credit growth, and GDP growth in Poland and Croatia, and GDP growth in Russia. U.S. stock-price movements significantly affect EMP, credit growth, and inflation in Bulgaria, and GDP growth in Russia and Ukraine. The other 
macroeconomic variables (such as the linkage between inflation and credit growth and Poland) have important effects as well.

These results are confirmed by our Generalized IRF results, which are presented in Figure 3. It is important to note that the IRFs on the far right of each column come from a set of separate estimations (which replace oil-price volatility with REER volatility). Since all but the "replacement" variables' IRFs will be the same, to avoid redundancy and to conserve space, only the REERVOL IRFs are depicted. We can easily see the differences in response to shocks in each variable. Also, only those responses that are more than two standard errors from zero (using the error bands) are considered to be significantly positive or negative.

Our main conclusion from the IRFs is that macroeconomic variables respond differently to oil-price and REER shocks. In many cases, higher U.S. stock prices reduce EMP (and falling prices put pressure on the region's currencies); high stock prices are often beneficial to the region's growth. While there is a vast amount of information in these graphs, we can focus on some key results, country by country. In Poland, for example, oil-price volatility raises EMP and increases credit growth, while REER volatility reduces credit growth. Here, we see that the two types of external risk - oil-price variability and REER volatility — do indeed have different effects.

In Hungary, REER volatility reduces EMP as well as credit growth, but oil prices have less of an effect. Oil-price volatility increases Croatian credit growth, but REER volatility does not have the same effect. For Bulgaria, only limited effects are observed overall. Neither oil-price variability nor REER volatility generate significant impulse responses for any of Bulgaria's key macroeconomic variables in our study. Perhaps differences in the country's exchange-rate regime (it alone has a currency-board-type fixed exchange rate; others have floating currencies) might explain these differences.

Turning to the two countries that are most closely tied to energy prices, we arrive at some interesting conclusions. In Russia, oil-price volatility increases EMP and reduces industrial production growth, confirming that recent fluctuations in global energy markets will help destabilize not only the ruble (RUB), but also Russia's real economy. At the same time, increased REER volatility leads to higher growth, which demonstrates the differences in responses to these two risk measures. In Ukraine, oilprice volatility increases credit growth, while REERVOL reduces the same macroeconomic variable. The hryvnia is not affected the way the ruble was in our analysis.

These findings bring us to two key conclusions. First, business leaders and policymakers must be wary of the role that commodity-price fluctuations have on the macroeconomies of the countries in which they operate. But, since this role varies from country to country, a "one size fits all" policy is not recommended, and policies must therefore be tailored depending on the importance of oil prices and the impact that risk has on each particular economy. 
Figure 3: Impulse-response functions (with \pm 2 standard error bands)

\section{Poland}
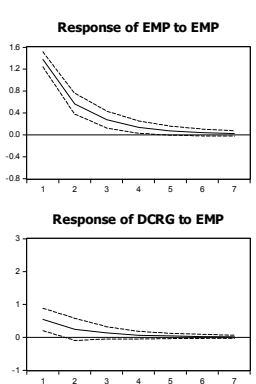

Response of GROWTH to EMP

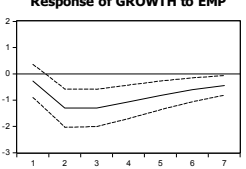

\section{Hungary}
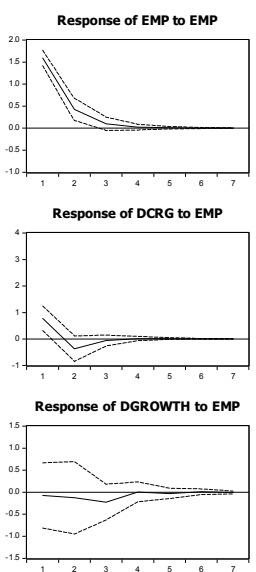

\section{Croatia}
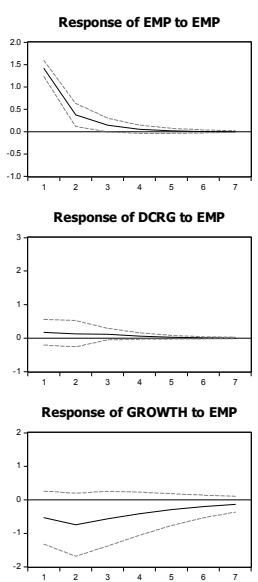

Response to Generalized One S.D. Innovations \pm 2 S.E. Response of EMP to DCRG

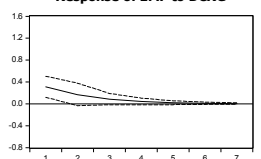

Response of DCRG to DCRG

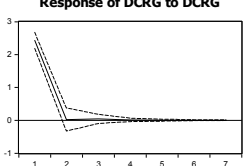

Response of GROWTH to DCRG

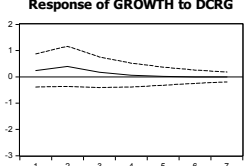

Response to Generalized One S.D. Innovations \pm 2 S.E.

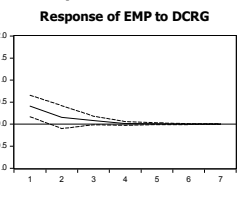

Response of DCRG to DCRG

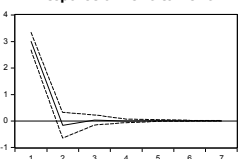

Response of DGROWTH to DCRG
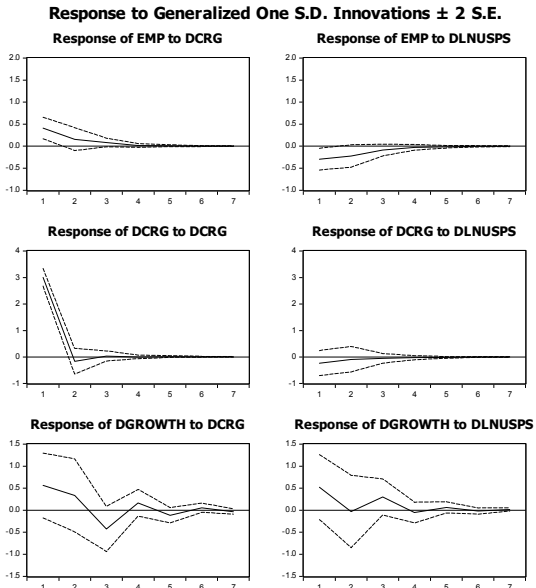

Response of DCRG to DLNUSPS

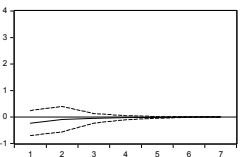

Response of DGROWTH to DLNUSPS

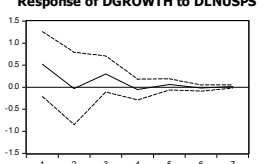

Response of EMP to DLNUSPS

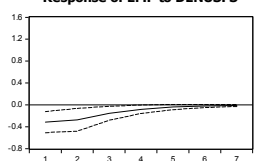

Response of DCRG to DLIUSPS

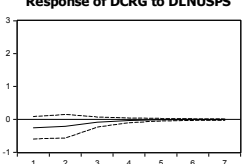

Response of GROWTH to DLNUSPS
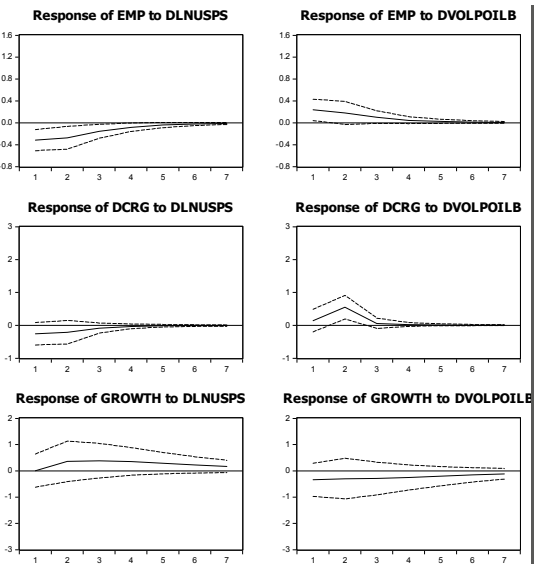

Response of DCRG to DVOLPOILB
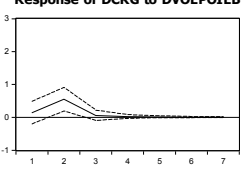
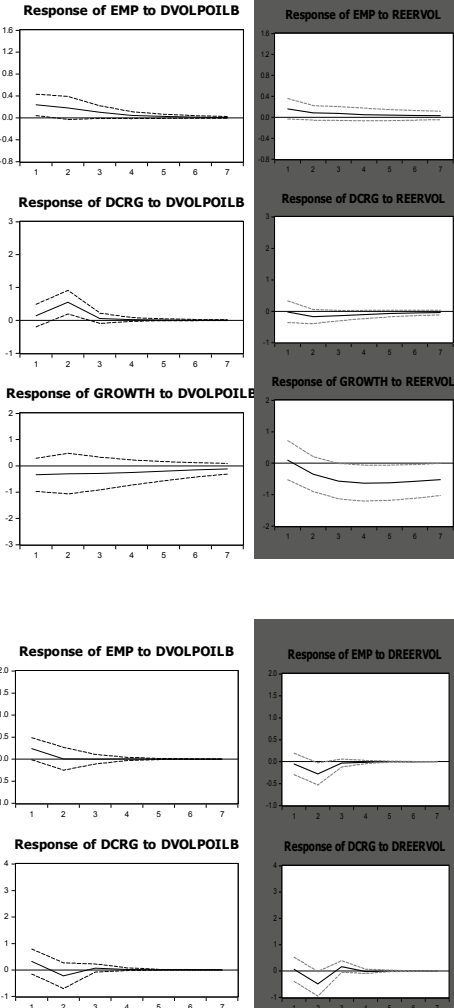

Response of DGROWTH to DVOLPOIL

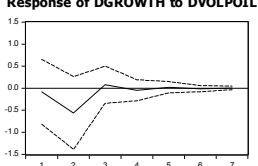

Response to Generalized One S.D. Innovations \pm 2 S.E.
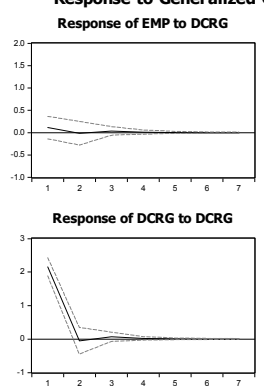

Response of GROWTH to DCRG

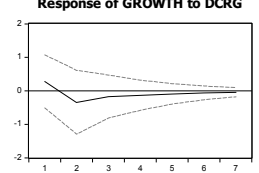

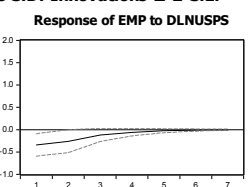

Response of DCRG to DLNUSPS

Response of EMP to DVOLPOIL

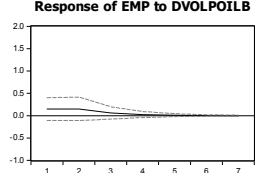

Response of DCRG to DVOLPOILB

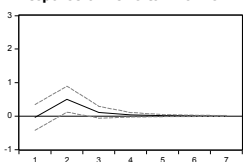

Response of GROWTH to DVOLPOIL

Response of GROWTH to DLNUSPS

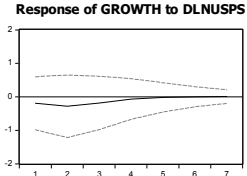

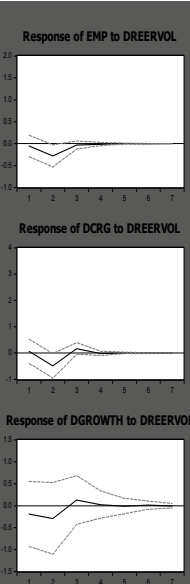

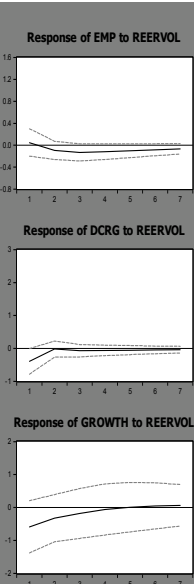




\section{Bulgaria}
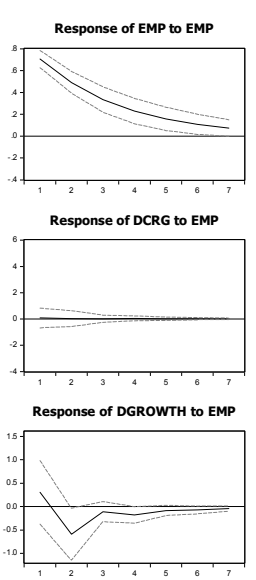

\section{Russia}
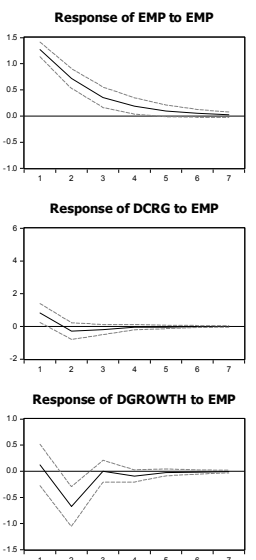

\section{Ukraine}
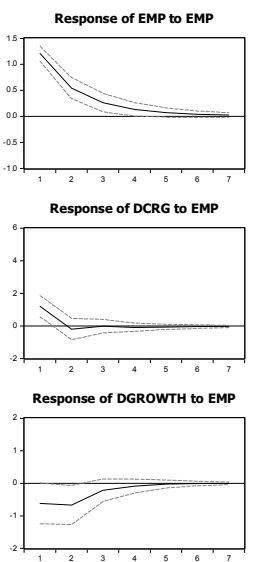

Response to Generalized One S.D. Innovations \pm 2 S.E. Response of EMP to DCRG
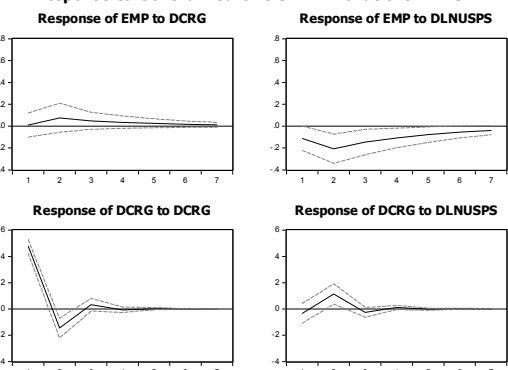

Response of DGROWTH to DCRG
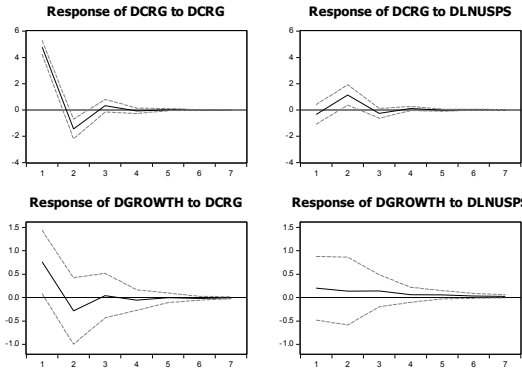

Response to Generalized One S.D. Innovations \pm 2 S.E. Response of EMP to DCRG

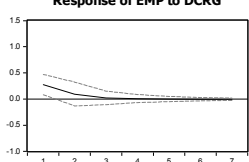

Response of DCRG to DCRG

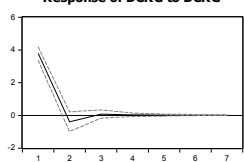

Response of DGROWTH to DCRG

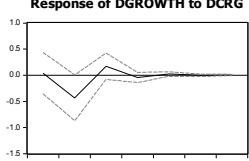

Response of DGROWTH to DLNUSPS
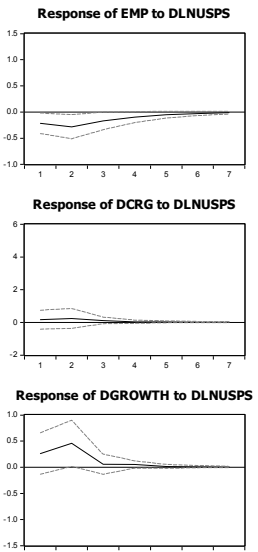

Response to Generalized One S.D. Innovations \pm 2 S.E. Response of EMP to DCRG
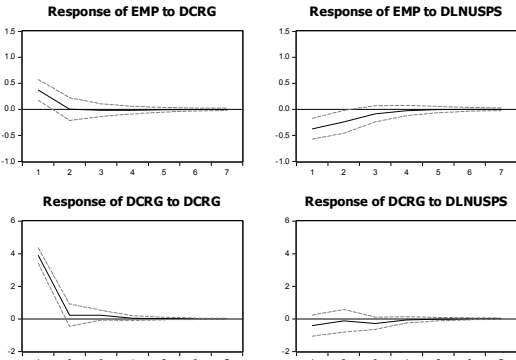

Response of DGROWTH to DCRG

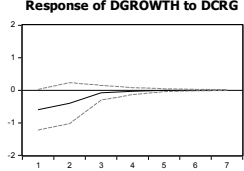

Response of DCRG to DLNUSPS

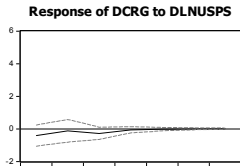

Response of DGROWTH to DLNUSPS

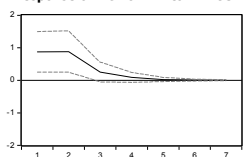

Response of DCRG to DVOLPOILB

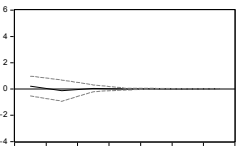

Response of DGROWTH to DVOLPOILE
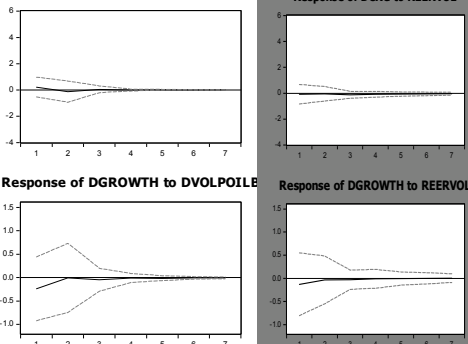

Response of EMP to DVOLPOILB

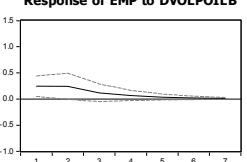

Response of DCRG to DVOLPOILB

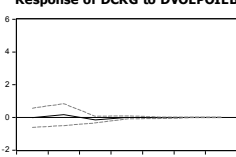

Response of DGROWTH to DVOLPOILE
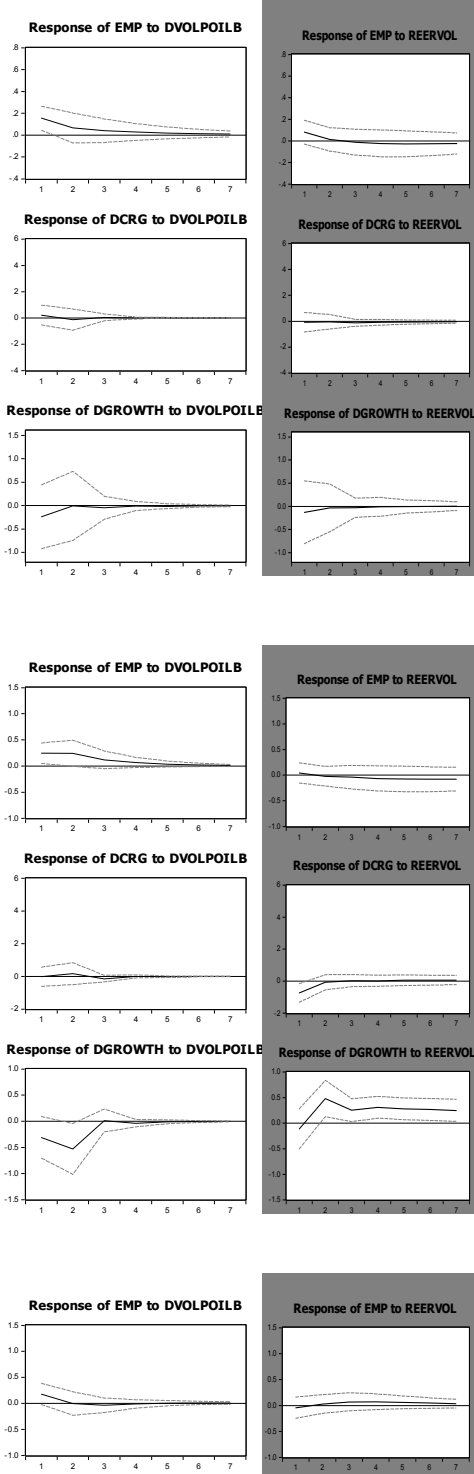

Response of DCRG to DVOLPOILB

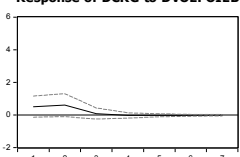

Response of DCRG to REERVOL

Response of DGROWTH to DVOLPOI
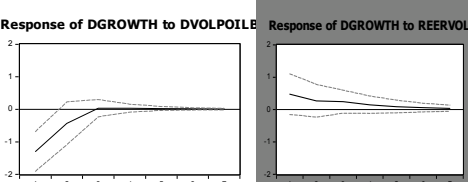


\section{Conclusion}

Commodity-price volatility, which has increased over the past year with the recent plunge in oil prices, has the potential to introduce risk into the business environment. In particular, CEE countries might find the costs of this risk to outweigh the benefits brought by high energy prices. Therefore, those who conduct business in the region must be aware of how risk affects each variable in the macroeconomy, and how these effects differ from country to country.

This study models oil-price and real effective exchange rate (REER) risk for six CEE economies before using Vector Autoregressive (VAR) methods to test for spillovers between risk and a set of macroeconomic variables. First, a measure of Exchange Market Pressure (EMP) is created for each country to obtain a measure of currency movements and central bank interventions combined. Risk in oil prices and the REER is also calculated using statistical methods, and these variables are used alongside a number of macroeconomic variables in our empirical analysis.

We test our hypothesis using Granger causality tests and by generating Impulse Response Functions. Our results show that oil-price and REER volatility have differing effects on our set of macroeconomic variables, and that overall the results differ from country to country. In general, U.S. stock price decreases put pressure on the region's currencies. We find that credit growth and output growth are most affected by oil-price risk, but not for every country in the study. In particular, oil-price risk puts pressure on the złoty and leads to increased credit growth in Poland, while REER volatility has more of an impact on Hungary's economy. Russia, the region's major oil exporter, experiences not only pressure to depreciate, but also reduced GDP growth, when oilprice risk increases. We conclude that differences in economic performance in the region are real, and that policymakers and business leaders must take these differences into account when planning their strategies.

\section{References}

1. Hegerty, S.W. (2012): How Integrated are the Exchange Markets of the Baltic Sea Region? An Examination of Market Pressure and its Contagion, Baltic Journal of Economics, 12(2), pp. 109-122. http://dx.doi.org/10.1080/1406099x.2012.10840520

2. Hegerty S.W. (2014a): Exchange Market Pressure, Commodity Prices, and Contagion in Latin America, Journal of International Trade \& Economic Development, 23(1), pp. 56-77. http://dx.doi.org/10.1080/09638199.2012.679292

3. Hegerty, S.W. (2014b): Exchange Market Pressure and Price Spillovers in Russia, Ukraine, and Belarus, Applied Econometrics and International Development, 14(2).

4. Koseoglu, S.D.; Cevik, E.I. (2013): Testing for Causality in Mean and Variance Between the Stock Market and the Foreign Exchange Market: An Application to the Major Central and Eastern European Countries, Czech Journal of Economics and Finance (Finance a uver), 63(1), pp. 65-86

5. Pesaran, M.H.; Shin, Y. (1998): Generalised Impulse Response Analysis in Linear Multivariate Models, Economics Letters, 58, pp.17-29. http://dx.doi.org/10.1016/s01651765(97)00214-0

6. Phillips, P.; Perron, P. (1988): Testing for a Unit Root in Time Series Regression, Biometrica, 75, pp. 335-346. http://dx.doi.org/10.1093/biomet/75.2.335 
7. Phylaktis, K.; Ravazzolo, F. (2005): Stock Prices and Exchange Rates Dynamics, Journal of International Money and Finance, 24(7), pp. 1031-1053.

8. Sims, C.A (1980): Macroeconomics and Reality, Econometrica 48, pp. 1-48. http://dx.doi.org/10.2307/1912017

9. Stavárek, D. (2011): Comparison of Exchange Market Pressure Across the New Part of the European Union, Emerging Markets Finance and Trade, 47, iss. sup 3. http://dx.doi.org/10.2753/ree1540-496x4704s302

10. Van Poeck, A.; Vanneste, J.; Veiner, M. (2006): Exchange Market Pressure in the Formerly Planned Central and Eastern European Countries: The Role of Institutions, Tijdschrift voor Economie en Management, 51(3), pp. 309-46. 
